\title{
Faculty Participation in Teaching Improvement Programs
}

\author{
ELIZABETH S. BOTMAN* and ALEXANDER D. GREGOR**
}

\begin{abstract}
A study undertaken to explore faculty nonparticipation in teaching improvement programs is described. Faculty nonparticipation was viewed as a function of interacting personal and situational factors. Questionnaire results, representing 30 percent of the academic faculty at a major university, were compared along disciplinary lines and according to participation in instructional workshops. Responses of past participants and nonparticipants were compared in order to identify variables associated with nonparticipation in instructional development activities. Approximately one-quarter of the 213 respondents had participated in teaching improvement workshops at least once since 1971. Respondents from the Professions and Applied Sciences appeared generally most supportive of the concept of T.I.P.'s while respondents from the Faculty of Science appeared to be the least positive. The study results suggest that faculty nonparticipation in T.I.P.'s may be associated with: the professor's views about teaching and teaching improvement; the relative personal priority assigned to teaching; the perceived need for improvement in teaching skills; attitudes towards the teaching improvement program; awareness of available programs; and the perceived convenience of available programs. The perceived level of university support for good teaching was less clearly associated with nonparticipation, and perceived situational barriers were not found to be associated.
\end{abstract}

\section{RÉSUMÉ}

Dans ce travail, l'auteur décrit une étude tentant d'explorer la non-participation des enseignants d'une université au programme de perfectionnement de l'enseignement (T.I.P.). La non-participation des enseignants se voit comme étant la conséquence de l'interaction de facteurs personnels et de facteurs de situations d'en-

* M.Ed. graduate in Adult and Postsecondary Education, Department of Educational Administration and Foundations, University of Manitoba.

** Professor, Department of Educational Administration and Foundations, University of Manitoba. 
seignement dans lesquelles se trouvent les professeurs. L'auteur a analysé les résultats d'un questionnaire, représentant 30 pour cent du personnel académique d'une université de grande taille selon les disciplines enseignées par les professeurs et selon leur participation aux ateliers d'enseignement. La comparaison des réactions des anciens participants et des non-participants fut effectuée afin d'identifier les variables reliées à la non-participation aux activités de perfectionnement. Environ un quart des 213 réponses venaient de professeurs qui avaient participé au moins une fois à des ateliers de perfectionnement de l'enseignement depuis 1971. Les réponses du personnel des professions et des Sciences Appliquées semblaient en général appuyer le concept des ateliers de perfectionnement de l'enseignement tandis que celles du personnel de la Facultë des Sciences semblaient être les moins positives au concept. L'enquête suggère que la non-participation des professeurs aux ateliers de perfectionnement de l'enseignement peut être due aux facteurs suivants: à la philosophie du professeur envers l'enseignement et envers le perfectionnement de son enseignement; à la priorité personnelle qu'il accorde à l'enseignement; au besoin qu'il éprouve de se perfectionner dans les techniques d'enseignement; aux attitudes qu'il a envers le programme de perfectionnement de l'enseignement; a la connaissance qu'il a des programmes disponibles; et à la disponibilité du professeur vis-u-vis l'horaire des programmes. La perception de l'appui universitaire pour un bon enseignement était moins nettement relièe à la non-participation et les difficultès de situations redoutées n'étaient pas valables.

\section{INTRODUCTION}

Traditionally, publicly articulated university goals have encompassed teaching, research and service. Faculty collective agreements as well as university policy statements seem to encourage faculty members to strive for excellence in these functions (Campbell, 1981; Trotter, 1974). Yet the literature suggests that concern over quality of instruction and the priority accorded to it remain as issues. One response to this concern has been the establishment of various forms of teaching improvement centres and programs (Shore, 1979; Hedley, 1980).

Although research results generally have supported the value of teaching improvement programs (T.I.P.'s), the evidence may be considered equivocal, and T.I.P. administrators have expressed concern over relatively low faculty participation rates (Geis and Smith, 1979). The reasons why faculty members choose not to participate in instructional development activities have been the subject of conjecture, but of relatively little empirical scrutiny, although a number of writers have stressed the urgent need for research in the area.

The main goal of this study was to explore faculty nonparticipation in the teaching improvement program (entitled University Teaching Service) at one major Canadian university. Various factors thought to be related to nonparticipation 
were investigated in the hope of yielding descriptive data which might contribute to current theory and provide practical assistance to university policy-makers and T.I.P. administrators.

A conceptual framework was adopted which viewed faculty participation as the result of the interaction between a variety of personal (psychological or attitudinal) and situational (external or environmental) forces. Previous researchers in the field of adult education (Bock, 1980; Boshier, 1973; Cross, 1981; Miller, 1967) have utilized similar approaches to viewing participation.

\section{METHODOLOGY}

It was decided that descriptive research methods would be most suitable in capturing a "snapshot" of current faculty opinions, beliefs, expressed reasons for nonparticipation and other data possibly related to T.I.P. participation. A group interview with selected (but not representative) faculty members was used to solicit preliminary "natural language" perceptions of reasons for general faculty nonparticipation. A complete review of related literature provided further possible explanations.

This stage provided a basis for development of the main data collection instrument. A detailed mailed questionnaire was developed, pretested and revised. Appropriate survey methods were adopted to enhance instrument content and construct validity, reliability and response rate.

The specific aims of the study necessitated the collection of demographic data, details of the respondents' past and prospective participation in the University Teaching Service (U.T.S.) programs, and faculty opinions regarding teaching and teaching improvement. Respondents who had never participated in T.I.P. programs were invited to give an explanation for their nonparticipation. Provision was made as well for additional written comments and suggestions from all respondents.

In line with earlier studies undertaken at this institution, the respondents were divided into four roughly equal groupings: Arts; Science; Applied Sciences (e.g., Agriculture, Engineering, Medicine); and Professions (e.g., Law, Education, Administrative Studies).

A proportional random sample representing 30 percent of the full-time academic faculty at the university was selected. A total of 400 surveys were mailed to the sample through the campus mail. Vigorous follow-up procedures, including two follow-up mailings, were employed. Although the research schedule required the questionnaire to be distributed during the summer months (considered to be a "difficult" time of the year), an overall response rate of 53 percent resulted. The 213 usable surveys constituted a 16 percent sample of the population. Examination of the demographic data revealed that respondents represented the population with respect to age group, sex, academic rank and general faculty or discipline area.

The survey data were fed into the central university (Amdahl) computer 
system and the Statistical Package for Social Sciences (S.P.S.S.) was utilized to calculate descriptive summary statistics and to determine statistically significant (at 0.05 level) differences between responses of subgroups. Comparison of responses between subgroups constituted the main method of data analysis. In addition, content analysis was performed on the wealth of written comments provided by the respondents.

\section{FINDINGS}

The data indicated that the respondents from Arts, Science, the Professions and the Applied Sciences had consistently different views on the issues explored. For example, the respondents from the Professions and the Applied Sciences expressed higher overall need for improvement in their teaching abilities and much more positive attitudes towards the local T.I.P. than did the respondents from the Faculties of Arts and Science. The data suggested that the Science respondents felt the least need for improvement and had the least favorable attitudes towards both teaching improvement and teaching improvement programs.

A further division of the respondents was made on the basis of whether they had in fact ever attended a teaching improvement program or, if not, whether they were likely to in the future (as inferred from their responses to various items). This division produced groupings of approximately one-half, one-quarter and one-quarter, as follows:

TABLE 1

Participation Status of Respondents

\begin{tabular}{l|c|c}
\hline Potential Participation Status & $\begin{array}{c}\text { Number of } \\
\text { Respondents }\end{array}$ & $\begin{array}{c}\text { Percentage of all } \\
\text { respondents }\end{array}$ \\
\hline $\begin{array}{l}\text { Respondents who attended University } \\
\text { Teaching Service workshops in past } \\
\text { (Past Participants) }\end{array}$ & 55 & 25.8 \\
$\begin{array}{l}\text { Respondents who have not attended } \\
\text { University Teaching Service workshops } \\
\text { but who expressed possible interest in } \\
\text { future participation } \\
\text { (Potential Participants) }\end{array}$ & 102 & 47.9 \\
$\begin{array}{l}\text { Respondents who have not attended } \\
\text { University Teaching Service workshops } \\
\text { and who stated they have no intention } \\
\text { of future participation } \\
\text { (Unlikely Participants) }\end{array}$ & 45 & 21.1 \\
$\begin{array}{l}\text { Unknown } \\
\text { Total }\end{array}$ & 11 & 100 \\
\hline
\end{tabular}

These groupings in their turn proved to have a number of statistically significant differences in response to survey items. Not surprisingly, the past participants appeared to hold the most positive views and the "unlikely" participants voiced the least favorable.

The main effort of data analysis was devoted to comparison of the responses of the past participants in the T.I.P. (about 25 percent) and the responses of the remaining nonparticipants. Themes or variables thought to be associated with non- 
participation in University Teaching Service teaching workshops were explored in detail by using direct survey question responses and by inferring from attitude items and respondents' comments.

\section{FACULTY ATTITUDES}

\section{Teaching and Teaching Improvement}

The respondents' personal views and attitudes towards teaching and teaching improvement appeared to be strongly related to T.I.P. participation. The data suggested that nonparticipant respondents were significantly less positive than past participants in their attitudes towards teaching improvement and in their confidence in the efficacy and possible benefits of T.I.P. participation. Nonparticipants were also much more likely to agree that actual teaching experience is the best preparation for teaching and that further specialized subject study is the best strategy for teaching improvement. The evidence also indicated that more nonparticipants than past participants believed that attendance at a teaching workshop may suggest that one's teaching ability is inadequate. Table 2 indicates a number of survey items eliciting significantly different (at the .05 level) attitudes towards the issue of teaching improvement.

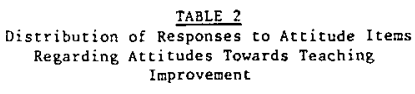

\begin{tabular}{|c|c|c|c|c|c|c|c|c|c|}
\hline \multirow[t]{3}{*}{ Acticude Item } & \multicolumn{5}{|c|}{ Overall Responses } & \multicolumn{4}{|c|}{ Participation Analysis } \\
\hline & \multicolumn{5}{|c|}{ Percentages } & \multirow{2}{*}{$\begin{array}{l}\text { Participation } \\
\text { Status }\end{array}$} & \multicolumn{3}{|c|}{ Percentages * } \\
\hline & SD & $\mathrm{D}$ & $\mathrm{N}$ & A & SA & & $\mathrm{D}$ & $\mathrm{N}$ & $\mathrm{A}$ \\
\hline $\begin{array}{l}\text { It is possible to improve teaching } \\
\text { effectiveness by means of a specialized } \\
\text { course about teaching. }\end{array}$ & 1.9 & 8.9 & 21.1 & 58.7 & 6.1 & $\begin{array}{l}\text { Past Part. } \\
\text { Nonpart. }\end{array}$ & $\begin{array}{r}5.7 \\
12.3\end{array}$ & $\begin{array}{l}13.2 \\
24.7\end{array}$ & $\begin{array}{r}81.1 \\
.63 .0\end{array}$ \\
\hline $\begin{array}{l}\text { Protessors from all areas can benefit } \\
\text { from interdisciplinary programs offered } \\
\text { by pedagogical experts. }\end{array}$ & 0.5 & 13.2 & 22.1 & 52.6 & 7.5 & $\begin{array}{l}\text { Past Part. } \\
\text { Nonpart. }\end{array}$ & $\begin{array}{r}5.7 \\
17.9\end{array}$ & $\begin{array}{l}13.2 \\
26.9\end{array}$ & $\begin{array}{l}81.1 \\
55.2\end{array}$ \\
\hline $\begin{array}{l}\text { University professors best learn how } \\
\text { to teach through actual teaching } \\
\text { experience. }\end{array}$ & 0 & 20.1 & 22.1 & 49.8 & 3.8 & $\begin{array}{l}\text { Past Part. } \\
\text { Nonpart. }\end{array}$ & $\begin{array}{l}34.6 \\
15.9\end{array}$ & $\begin{array}{l}19.2 \\
24.8\end{array}$ & $\begin{array}{l}46.2 \\
59.3\end{array}$ \\
\hline $\begin{array}{l}\text { The best strategy to improve one's } \\
\text { teaching is to facilitate further study } \\
\text { in one's specialty area. }\end{array}$ & 1.9 & 46.0 & 23.0 & 22.1 & 4.2 & $\begin{array}{l}\text { Past Part. } \\
\text { Nonpart. }\end{array}$ & $\begin{array}{l}67.9 \\
44.2\end{array}$ & $\begin{array}{l}11.3 \\
27.9\end{array}$ & $\begin{array}{l}20.8 \\
27.9\end{array}$ \\
\hline $\begin{array}{l}\text { Attendance at a teaching workshop may } \\
\text { suggest that a professor's teaching is } \\
\text { in some way inadequate. }\end{array}$ & 16.9 & 42.3 & 13.1 & 20.7 & 3.3 & $\begin{array}{l}\text { Past Part. } \\
\text { Nonpart. }\end{array}$ & $\begin{array}{l}76.9 \\
56.9\end{array}$ & $\begin{array}{r}3.8 \\
16.4\end{array}$ & $\begin{array}{l}19.2 \\
26.7\end{array}$ \\
\hline
\end{tabular}

$$
\begin{aligned}
& \text { * To facilitate valid comparisons, agreement ( } S A+A \text { ) was considered as one category, and disagreement (SD + D) } \\
& \text { as one category. } \\
& \text { LEGEND: SD : strongly disagree } \\
& \mathrm{D} \text { : disagree } \\
& \text { : neutral or no opinton } \\
& \text { A : agree } \\
& \text { SA : strongly agree }
\end{aligned}
$$

The survey findings also suggested that nonparticipants assigned much lower personal priority to teaching than did past T.I.P. participants. Nonparticipants (in comparison to past participants) appeared to enjoy teaching less, to spend 
less time teaching, to feel that their colleagues are less committed to teaching, and to have other more urgent priorities (such as research) (cf. Table 3 below).

\section{TABLE 3}

Attitudes Toward Teaching and Teaching Improvement

\begin{tabular}{|c|c|c|c|c|c|c|c|c|c|}
\hline \multirow[b]{3}{*}{ Atcicude Item } & \multicolumn{5}{|c|}{ Overa11 Responses } & \multicolumn{4}{|c|}{ Participation Analysis } \\
\hline & & Pers & entag & & & Participation & & centa & \\
\hline & SA & $\mathrm{D}$ & $\mathrm{N}$ & $A$ & SA & Status & $n$ & $\mathrm{~N}$ & $A$ \\
\hline $\begin{array}{l}\text { Teaching is the most satisfying and } \\
\text { enjoyable aspect of professional work. }\end{array}$ & $1 \div 4$ & 17.4 & 18.3 & 42.3 & 17.8 & $\begin{array}{l}\text { Past Part. } \\
\text { Nonpart. }\end{array}$ & $\begin{array}{l}12.1 \\
23.0\end{array}$ & $\begin{array}{l}11.1 \\
22.6\end{array}$ & $\begin{array}{l}77.8 \\
54.1\end{array}$ \\
\hline $\begin{array}{l}\text { Professors in my department appear to be } \\
\text { highly committed to teaching. }\end{array}$ & 0.5 & 14.1 & 24.4 & 52.1 & 5.2 & $\begin{array}{l}\text { Past Part. } \\
\text { Nonpart. }\end{array}$ & $\begin{array}{r}7.7 \\
17.8\end{array}$ & $\begin{array}{l}17.3 \\
28.1\end{array}$ & $\begin{array}{l}75.0 \\
54.1\end{array}$ \\
\hline $\begin{array}{l}\text { The U.T.S. Teaching workshops cake too } \\
\text { much time from more urgent priorities. }\end{array}$ & 3.3 & 16.9 & 31.9 & 21.6 & 3.3 & $\begin{array}{l}\text { Past Part, } \\
\text { Nonpart. }\end{array}$ & $\begin{array}{l}57.1 \\
11.7\end{array}$ & $\begin{array}{l}20.4 \\
51.4\end{array}$ & $\begin{array}{l}22.4 \\
36.9\end{array}$ \\
\hline $\begin{array}{l}\text { I feel the need to improve ny } \\
\text { instructional abilities. }\end{array}$ & .05 & 14.1 & 24.4 & 52.1 & 5.2 & $\begin{array}{l}\text { Past Part. } \\
\text { Nonpart. }\end{array}$ & $\begin{array}{r}5.7 \\
21.2\end{array}$ & $\begin{array}{l}13.2 \\
19.9\end{array}$ & $\begin{array}{l}81.1 \\
58.9\end{array}$ \\
\hline $\begin{array}{l}\text { I am capable of handling any improvenent } \\
\text { that may be necessary for my teaching. }\end{array}$ & 0 & 13.6 & 33.3 & 44.6 & 3.3 & $\begin{array}{l}\text { Past Part. } \\
\text { Nonpart. }\end{array}$ & $\begin{array}{l}25.5 \\
10.4 \\
\end{array}$ & $\begin{array}{l}33.3 \\
36.1 \\
\end{array}$ & $\begin{array}{l}41.2 \\
53.5 \\
\end{array}$ \\
\hline
\end{tabular}

- To Eacilitate valid comparisons, agrement ( $S A+A$ ) was considered as one category, and disagreement (SD + D) as one category.

\section{Attitudes Towards the Institution's Program}

The attitudes held by respondents towards the specific T.I.P. in the institution also appeared to be related to participation. Despite a generally positive overall evaluation of the university's program, nonparticipants expressed significantly less favorable opinions than past participants (cf. Table 4 below). Nonparticipants were far less likely than past participants to agree that T.I.P. activities appear to be worthwhile, effective in improving instruction and successful in meeting the needs and interests of faculty members. It appears that nonparticipant respon-

TABLE 4

Distribution of Responses to Attitude Items Regarding Attitudes Towards University Teaching Service Workshops

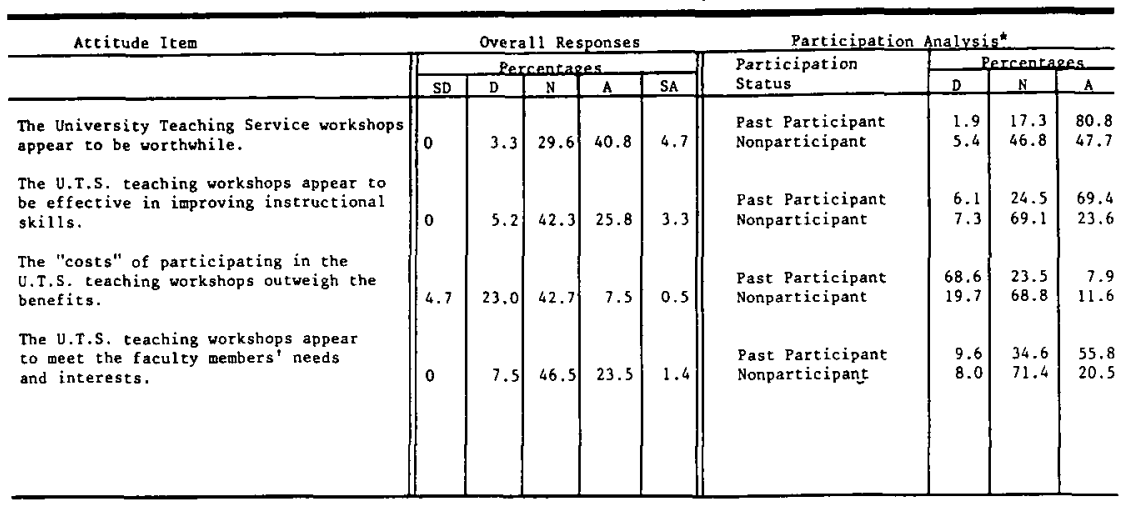


dents would desire "hard" evidence that the T.I.P. activities are effective and worthwhile, in order to weigh the relative costs and to be convinced of the benefits of attendance.

Further revealing comparisons emerged when respondents were asked a "general impression" question about the university program (cf. Table 5 below).

TABLE 5

Responses to a "general impression" question about the university program

\begin{tabular}{|c|c|c|c|c|c|c|c|c|}
\hline \multirow[b]{3}{*}{$\begin{array}{l}\text { Overall impressio } \\
\text { of University } \\
\text { Teaching Service }\end{array}$} & \multirow[t]{2}{*}{$\begin{array}{l}\text { Overall } \\
\text { I. Response }\end{array}$} & \multicolumn{4}{|c|}{ II.Faculty Group Analysis } & \multicolumn{3}{|c|}{$\begin{array}{l}\text { Potential Participation } \\
\text { Analysis }\end{array}$} \\
\hline & & Arts & Science & Prof. & $\begin{array}{l}\text { App. } \\
\text { Sc. }\end{array}$ & $\begin{array}{l}\text { Past } \\
\text { Part. }\end{array}$ & $\begin{array}{l}\text { Potent } \\
\text { Part. }\end{array}$ & $\begin{array}{l}\text { Unlikely } \\
\text { Part. }\end{array}$ \\
\hline & & & & & Percen & tages & & \\
\hline $\begin{array}{l}\text { No opinion } \\
\text { Favorable } \\
\text { Ambivalent } \\
\text { Unfavorable }\end{array}$ & $\begin{array}{r}36.2 \\
38.5 \\
18.3 \\
2.3\end{array}$ & $\begin{array}{r}41.2 \\
32.4 \\
23.5 \\
2.9\end{array}$ & $\begin{array}{r}54.5 \\
9.1 \\
27.3 \\
9.1\end{array}$ & $\begin{array}{r}30.4 \\
53.6 \\
14.3 \\
1.8\end{array}$ & $\begin{array}{r}38.6 \\
43.2 \\
17.0 \\
1.1\end{array}$ & $\begin{array}{r}20.4 \\
72.2 \\
5.6 \\
1.9\end{array}$ & $\begin{array}{r}46.5 \\
30.7 \\
21.8 \\
1.0\end{array}$ & $\begin{array}{r}38.6 \\
25.0 \\
29.5 \\
6.8\end{array}$ \\
\hline
\end{tabular}

\section{Reasons for Nonparticipation}

Situational factors such as the faculty's level of awareness of the teaching improvement programs appeared to have less (although still significant) association with nonparticipation. It is worth nothing that twelve percent of all respondents claimed to have no source of information about the program (despite the fact that a university-wide informational mailing is undertaken each year). The data indicated that nonparticipant respondents were significantly less likely than past participant respondents to feel that they have sufficient information about the program upon which to base decisions.

Exploration of the respondents' perceptions regarding university support and rewards for good teaching revealed that although many respondents voiced definite concerns, the overall reactions of the past participants were as diverse as those of the nonparticipants. As might be expected, respondents appeared to agree that good teaching was not particularly rewarded within the university system, that personal satisfaction is the most influential reward (or motivator) and that research is considered to be the most important priority in promotion and tenure decisions.

The final theme explored regarding nonparticipation was the possibility that faculty members were being blocked or prevented from participating by institutional or situational barriers. The survey findings suggest that such discouraging forces were not significantly related to nonparticipation. In fact, past U.T.S. participants reported a significantly greater number of blocks than did nonparticipants.

Recognizing the fact that the most critical factors related to increasing faculty participation in U.T.S. workshops are the most difficult to do anything about (as, for example, changing socialized attitudes), an attempt was nonetheless made to identify strategies which the respondents felt might have some efficacy. The following table indicates the manner of response to this item. 
TABLE 6

Distribution of Responses to ttems Regarding

Suggestions to Increase Faculcy Participation in U.T.S. Workshops"

\begin{tabular}{|c|c|c|c|c|c|c|c|c|c|c|c|c|c|c|c|c|c|c|c|c|}
\hline \multirow[b]{2}{*}{$\begin{array}{l}\text { Checklist--Suggestions to } \\
\text { Increase Participation }\end{array}$} & \multicolumn{2}{|c|}{$\begin{array}{l}\text { Overall } \\
\text { I. Responses }\end{array}$} & \multicolumn{8}{|c|}{ II. Faculty Group Analysis } & \multicolumn{6}{|c|}{ III. Potential Participation } & \multicolumn{4}{|c|}{$\begin{array}{l}\text { Nonparcicipation } \\
\text { v. Analysis }\end{array}$} \\
\hline & & & \multicolumn{2}{|c|}{ Arcs } & \multicolumn{2}{|c|}{ Science } & \multicolumn{2}{|c|}{ Prof. } & \multicolumn{2}{|c|}{$\begin{array}{l}\text { Appl. } \\
\text { Sci. }\end{array}$} & \multicolumn{2}{|c|}{$\begin{array}{l}\text { Past } \\
\text { Part. }\end{array}$} & \multicolumn{2}{|c|}{$\begin{array}{l}\text { Potene. } \\
\text { Part. }\end{array}$} & \multicolumn{2}{|c|}{$\begin{array}{l}\text { Unlikely } \\
\text { Parc. }\end{array}$} & \multicolumn{2}{|c|}{$\begin{array}{l}\text { Past } \\
\text { Part. }\end{array}$} & \multicolumn{2}{|c|}{$\begin{array}{l}\text { Non- } \\
\text { Parc }\end{array}$} \\
\hline & $t$ & $x$ & $\mathrm{f}$ & $x^{7}$ & $f$ & $I$ & $t$ & $z$ & $\mathrm{t}$ & $\bar{x}$ & $t$ & $z$ & $t$ & $x$ & $t$ & 2 & $\mathrm{f}$ & $I$ & $f$ & $\mathrm{z}$ \\
\hline Increase publicicy & 88 & 41.3 & 12 & 32 & 6 & 27 & 30 & 54 & 40 & 43 & 27 & 49 & 49 & 48 & 10 & 22 & 27 & 49 & 60 & 40 \\
\hline $\begin{array}{l}\text { Encouragement trom deparcmenc head } \\
\text { Tailor courses to individual }\end{array}$ & 86 & 40.4 & 16 & 29 & 7 & 32 & 23 & 41 & 40 & 43 & 33 & 60 & 40 & 39 & $\|$ & 24 & 33 & 60 & 32 & 35 \\
\hline faculey needs & 78 & 36.6 & 12 & 32 & 6 & 27 & 25 & 45 & 35 & 37 & 21 & 38 & 65 & 66 & 11 & 24 & 21 & 38 & S6 & 38 \\
\hline Encouragement frow Dean/Director & 63 & 29.6 & 11 & 29 & 3 & 14 & 23 & 41 & 26 & 28 & 27 & 49 & 28 & 27 & 6 & 13 & 27 & 49 & 35 & 23 \\
\hline Provision tor independent study & 5) & 26.8 & 5 & 13 & 4 & 18 & 15 & 27 & 33 & 35 & 18 & 33 & 28 & 27 & 8 & 18 & 18 & 33 & 36 & 26 \\
\hline Publicize leader's nawes & ss & 25.8 & 8 & $2:$ & 2 & 9 & 22 & 39 & 23 & 24 & 16 & 29 & 32 & 31 & 6 & 13 & 16 & 29 & 38 & 26 \\
\hline Revard participation through & & & & & & & & & & & & & & & & & & & & \\
\hline promocion & s! & 23.9 & 11 & 29 & 6 & 27 & 16 & 29 & 18 & 19 & 15 & 2) & 26 & 25 & 9 & 20 & 15 & 27 & 35 & 23 \\
\hline Encouragement froto colleagues & so & 23.5 & 11 & 29 & 1 & $s$ & 14 & 25 & 24 & 26 & 19 & 3s & 25 & 25 & 5 & 11 & 19 & 3s & 30 & 20 \\
\hline Reinstace merit pay & 46 & 21.6 & 7 & 18 & s & 23 & 13 & 23 & 21 & 22 & 14 & 25 & 26 & 26 & 7 & 16 & 16 & 25 & $3 !$ & 21 \\
\hline Formal evaluation of instruction & $\therefore 3$ & 20.2 & $s$ & 13 & 3 & 14 & 14 & 25 & 21 & 22 & 18 & 33 & 22 & 22 & 2 & 4 & 18 & 33 & 26 & 16 \\
\hline Experts instead of colleagues & 4] & 20.2 & 4 & 11 & 1 & 5 & 12 & 21 & 26 & 28 & is & 27 & 21 & 21 & 3 & 11 & is & 27 & 26 & 17 \\
\hline Improve U.T.S. offerings & 34 & 16.0 & 6 & 16 & 2 & 9 & 9 & 16 & 17 & 18 & 16 & 29 & is & is & 2 & 4 & 16 & 29 & 17 & i! \\
\hline Yore advanced-level cuurses & 34 & 16.0 & 1 & 3 & 0 & 0 & 13 & 23 & 20 & $2 \mathrm{I}$ & 24 & 66 & 9 & 9 & 0 & 0 & 24 & 44 & 9 & 6 \\
\hline Iaprove concent of courses & 29 & 13.6 & 3 & 8 & 2 & 9 & 8 & 14 & 16 & 47 & 13 & 24 & 11 & 11 & 3 & 7 & 13 & 24 & 14 & 9 \\
\hline administration & 27 & 12.7 & 1 & 3 & 3 & 14 & 10 & 18 & 13 & 14 & 11 & 20 & 13 & 13 & 2 & 4 & 11 & 20 & 15 & 10 \\
\hline Establish full-time office of & & & & & & & & & & & & & & & & & & & & \\
\hline $\begin{array}{l}\text { Consuleancs } \\
\text { Adwinister through central }\end{array}$ & 26 & 12.2 & 1 & 3 & 2 & 9 & 8 & 16 & is & 16 & 8 & 15 & 16 & 16 & 1 & 2 & 8 & 15 & 17 & 11 \\
\hline $\begin{array}{l}\text { Admanser through central } \\
\text { adwinistration }\end{array}$ & 23 & 10.8 & 4 & 11 & 3 & 16 & 6 & 11 & 10 & 11 & 6 & 11 & 12 & 12 & 3 & , & 6 & 11 & 15 & 10 \\
\hline Increase use of leccures & 21 & 9.9 & 4 & 11 & 1 & 5 & 3 & 9 & i1. & 12 & 9 & 16 & 10 & 10 & 2 & 4 & 9 & 16 & 12 & 8 \\
\hline Change course scheduling & 13 & 6.1 & 0 & 0 & 2 & 4 & 2 & 4 & 9 & 10 & 3 & 9 & 7 & 7 & 0 & 0 & s & 9 & 7 & s \\
\hline Include new topics & 9 & 4.2 & 0 & 0 & 0 & 0 & 5 & 9 & 4 & 4 & 7 & 13 & 2 & 2 & 0 & 0 & i & 13 & 2 & 1 \\
\hline Decrease course length & 7 & 3.3 & 1 & 3 & 0 & 0 & 0 & 0 & 6 & 6 & 3 & s & 4 & 4 & 0 & 0 & 3 & 5 & 2 & $i$ \\
\hline Change course format & 3 & 1.4 & $i$ & 3 & 0 & 0 & 0 & 0 & 2 & 2 & 0 & 0 & 2 & 2 & 0 & 0 & 0 & 0 & 2 & i \\
\hline
\end{tabular}

- All data are presented -- no statistical comparlson procedures vere performed.

- The percentage scoras refer to the proportion of the respective subgroup. 
Interestingly, the reasons suggested by individuals as to why they did not attend T.I.P. sessions do not conform closely to their suggestions for general remediation of the situation (cf. Table 7 below).

TABLE 7

Distribution of Nonparticipants' Responses to Items Regarding Reasons for Nonparticipation in U.T.S. Workshops

\begin{tabular}{|c|c|c|c|c|c|c|c|c|c|c|c|c|c|c|}
\hline \multirow[b]{4}{*}{$\begin{array}{l}\text { Checklist Possible Reason(s) for Non- } \\
\text { Participation: }\end{array}$} & \multirow{2}{*}{\multicolumn{2}{|c|}{ I. Overall }} & \multicolumn{8}{|c|}{ Il. Faculty Group Analysis } & \multicolumn{4}{|c|}{$\begin{array}{l}\text { Potential Participa- } \\
\text { III. tion Analysis }\end{array}$} \\
\hline & & & \multicolumn{2}{|c|}{ Arts } & \multicolumn{2}{|c|}{ Science } & \multicolumn{2}{|c|}{ Prof. } & \multicolumn{2}{|c|}{$\begin{array}{l}\text { Appl. } \\
\text { Sc. }\end{array}$} & \multicolumn{2}{|c|}{ Pot. Part. } & \multicolumn{2}{|c|}{ Unlike1y Par } \\
\hline & $f$ & $z$ & $\mathrm{f}$ & $\%$ & $E$ & $\%$ & $\mathrm{f}$ & $\%$ & $f$ & $z$ & $\mathrm{f}$ & $z$ & $f$ & $z$ \\
\hline & & & & & & & & & & & & & & \\
\hline I do not have enough time & 70 & 46.7 & 13 & 50 & 4 & 19 & 19 & 53 & 32 & 49 & 51 & so & 19 & 42 \\
\hline I never contemplated attending & 40 & 26.7 & 10 & 39 & 7 & 33 & 11 & 31 & 11 & 17 & 17 & 17 & 22 & 49 \\
\hline Courses inconveniently scheduled & 30 & 20.0 & 2 & 8 & 2 & 10 & 9 & 25 & 16 & 25 & 29 & 28 & 1 & 2 \\
\hline I prefer other means improvement & 30 & 20.0 & 6 & 23 & 5 & 24 & 10 & 28 & 8 & 12 & 13 & 13 & 17 & 38 \\
\hline No need to improve teaching & 22 & 14.7 & 4 & 15 & 3 & 14 & 6 & 17 & 9 & 14 & 7 & 7 & 15 & 35 \\
\hline Insufficient rewards & 19 & 12.7 & 8 & 31 & 4 & 19 & 1 & 3 & 6 & 9 & 14 & 14 & 5 & 11 \\
\hline Teaching is not major priority & 16 & 10.7 & 4 & 15 & 1 & 5 & 4 & 11 & 7 & 11 & 11 & 11 & 5 & 11 \\
\hline Courses have poor reputation & 15 & 10.0 & 4 & 15 & 2 & 10 & 3 & 8 & 6 & 9 & 6 & 6 & 9 & 20 \\
\hline Teaching can't be taught in course & 14 & 9.3 & 3 & 12 & 4 & 19 & 2 & 6 & 5 & 8 & 2 & 2 & 12 & 27 \\
\hline Educational experts cannot help & 12 & 8,0 & 1 & 4 & 5 & 24 & 1 & 3 & 5 & 8 & 4 & 4 & 8 & 18 \\
\hline Not aware of courses & 11 & 7.3 & 3 & 12 & 0 & 0 & 1 & 3 & 7 & 11 & 8 & 8 & 2 & 4 \\
\hline Not interested in available courses & 10 & 6.7 & 2 & 8 & 5 & 24 & 1 & 3 & 2 & 3 & 3 & 3 & 7 & 16 \\
\hline Not interested in involvement & 10 & 6.7 & 2 & 8 & 2 & 10 & 3 & 8 & 3 & 5 & 1 & 1 & 9 & 20 \\
\hline May appear inadequate if attend & 5 & 3.3 & 1 & 4 & 1 & 5 & 0 & 0 & 3 & 5 & 4 & 4 & 1 & 2 \\
\hline
\end{tabular}

The large volume of written comments, criticisms and suggestions contributed by the survey respondents clearly indicated great interest and concern. These qualitative data provided an important dimension to the research findings and permitted valuable insight into respondents' views. Examination of the comments suggested that the faculty members individually were committed (or at least so declared themselves) to providing high quality instruction. Quite a few respondents appeared to be disheartened by what they perceived to be a lack of value placed upon teaching by the university. One individual, for example, lamented "that lip service is paid to promoting teaching excellence but in terms of promotion, tenure and stature within the University, virtually no effort is made to evaluate it and virtually no weight is given to it."

\section{CONCLUSIONS}

The data collected for this research generally support the views regarding nonparticipation in adult education activities found in the literature. For example, Gaff (1978) concluded that faculty pessimism regarding T.I.P. efficacy is related to faculty beliefs that teaching cannot be taught and that subject specialization is the best qualification for teaching. The impression that faculty have other more urgent priorities than teaching perhaps indicates an acceptance of the research model of excellence (Herschfield, 1980). Cross (1977) found surveyed 
professors to demonstrate a level of self-satisfaction which mitigated against attempts at self-improvement. Interestingly, the strong emphasis on university rewards and incentives found in the literature (Buhl, 1979; Mauksch, 1980) did not appear to differ significantly between past participants and nonparticipants.

The study suggests that the personal and situational factors which appear to influence participation are numerous and complex, and that simple solutions are likely to have minimal impact on faculty participation levels. As Eble (1972) suggested: "if college teaching is to be improved, diverse forces must change both attitudes and practices." Similarly, to influence faculty participation in teaching improvement programs, action on several fronts should be considered.

The survey data suggest that documented evidence demonstrating that teaching skills can be effectively taught and can result in increased student achievement might help convince skeptical faculty members (bearing in mind, of course, that the important issues of acceptable definition(s) and evaluation of effective teaching are still to be overcome).

More direct recommendations to help increase faculty participation centre on those situational changes which might encourage or facilitate such participation. Detailed information concerning the course content might help, and T.I.P. organizers clearly must ensure the maintenance of consistently high quality programming. Routine workshop evaluations by participants would provide regular feedback, and could be augmented by follow-up research to assess long-term impact.

While many respondents argued that increased publicity might increase participation, it is clear that word-of-mouth tends to be the most convincing communication method. Certainly the maintenance of a network of active "alumni" is an important element in this, on an informal collegial level. At least as important, however, will be the more formal discussions, within academic units and between unit heads and individual staff members. While it is clear from the responses that the attitudes (or presumed attitudes) of administrators are of considerable importance in an individual's decision as to whether or not to participate in a T.I.P., information is lacking as to what those administrators' attitudes are toward teaching improvement, and toward their own role in the matter. If, as the evidence suggests, attitudes toward teaching are very much discipline-specific, it is reasonable to assume that unit heads will tend to reflect them. Their potential as agents of change is thus rather problematic. Further study is clearly called for in this dimension.

In the interim, it seems that teaching improvement programs in heterogenous institutions must continue to grapple with the question of appropriate format, with two principal variations presenting themselves (Hedley, 1980): disciplinespecific programs, and common institution-wide programs. This study indicated a clear difference of attitudes on this matter, largely reflecting discipline affiliation. As in the case of Edward Sheffield's seminal study of teaching styles, the matter of teaching improvement strategies carries the same message: no one way. 


\section{REFERENCES}

Bock, L.K. Participation. In A.B. Knox (Ed.). Developing, Administering, and Evaluating Adult Education. San Francisco: Jossey-Bass, 1980.

Boshier, R. Educational Participation and Dropout: A Theoretical Model. Adult Education, 1975, 23(4), 255-282.

Buhl, L. Professional Development in the Interinstitutional Setting. In J. Lindquist (Ed.). Designing Teaching Improvement Programs. Washington, D.C.: The Council for the Advancement of Small Colleges, 1979.

Campbell, D.R. President's Report 1981. Winnipeg: University of Manitoba, 1981.

Cross, K.P. Adults As Learners. San Francisco: Jossey-Bass, 1981.

Cross, K.P. Not Can, But Will College Teaching Be Improved? New Directions for Higher Education, 1977, 5(1), 1-15.

Eble, K.E. Professors as Teachers. San Francisco: Jossey-Bass, 1972.

Gaff, J.G. Overcoming Faculty Resistance. New Directions for Higher Education, 1978, 6(4), 43-57.

Geis, G.L., \& Smith, R. Professors' Perceptions of Teaching and Learning : Implications for Faculty Development. Paper presented at Annual Meeting of American Educational Research Association, San Francisco; April, 1979. (ERIC Document Reproduction Service No. ED172 625)

Hedley, R.L. Survey of Provision for Academic Staff Development (U.K. and Canada), Winnipeg: University of Manitoba, 1980.

Hershfield, A.F. Education's Technological Revolution: An Event in Search of Leaders. Change, 1980, 12(8), 48-52.

Mauksch; H.O. What are the Obstacles to Improving Quality Teaching? Current Issues in Higher Education, 1980, 2(1), 49-56.

Miller, H.L. Participation of Adults in Education: A Force-Field Analysis. Occasional Papers, No. 14, Brookline, Mass.: Center for the Study of Liberal Education for Adults, 1967.

Shore, B.M. Canada - An Emphasis on Instructional Development. In D.C.B. Teather (Ed.). Staff Development in Higher Education. London: Kogan Page, 1979.

Trotter, B. The Teacher and the Goals of the University. In C.K. Knapper, et.al. (Eds.). If Teaching is Important. . . Toronto: Clark, Irwin and Co., 1977. 